（215）引張変形によって生じるセパレーションの発生について

(ラインパイプ材に扔けるセパレーンョン発生過程の考察その1)

日本鋼管技研福山哲夫平忠明

○平林清照

1)粕言 : 最近の高級ラインパイプ材においては、清浄銅にもかかわらず延性が高くなるにつれて、セ パレーションが多く見受けられる傾向にある。本報告はセパレーションの発生過程を解明する為に、引張過

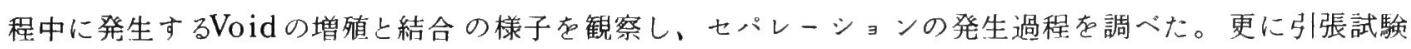
片のくびれ部の応力を測定する事によりセパレーションの発生する時の板厚方向応力を計算により求めた II)実験方法： 本実験に供試されたラインパイプ材の化学成分を表 1 に示す。丸棒引張試験で中止め試 験を行ない、QTMとS EMによって、Voidの発生位置と增殖及び結合を経てセパレーションに至る過程 を調へた。更にくびれ部の板厚方向応力 $大=\frac{a}{2 \gamma} \cdot \frac{P, A m}{1+a}$ (1) 式で求め、セバレーションの発生する応 力を求めた。( $\mathrm{P}$ : 荷重, $\mathrm{Am}$ :くび扎部の断面皘, $\mathrm{a}:$ くびれ部の半径 $\gamma:$ くびれ部の曲率半径) 四)結果：(1) セパレーションは鋼A.Cに発生し、鈰Bは発生しない。(但し衝撃荷重の場合はいず扎も顕著

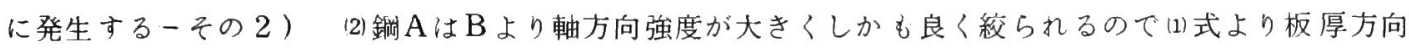
応力は大きくなり、破断寸前の $25 \%$ 伸び以上でセパレーションが発生し破断した。この時の配 $=44 \mathrm{~kg} / \mathrm{md}$ であった。Bは 率とサイズを測定した所、A め䄳增加と共に面積率と\#イズの增加は顕著になる。破断寸前で急激にVoidの結合が進み、A からセパレーションを経て破断するか、Bはcrackから破断に至る。同一丕てはAのVoid\%はBより多く 図 1 の様に針状傾向であるの対し、Bは角型Voidが多かった。(4)SEMで観察した結果、Voidの発生位置 が介在物と粒界及び粒内析出物を起点とするAのVoidは数が多く、連結して七パレーションに進展するが Bの場合は数も少なく、Voidが連結して面の異なる他の結晶粒界に達した時に連結は止まりセパレーショ ンに至らない。REM系又は $\mathrm{Nb}(\mathrm{CN})$ 系の介在物から生じたVoidはセパレーションに至らず、セパレーションの

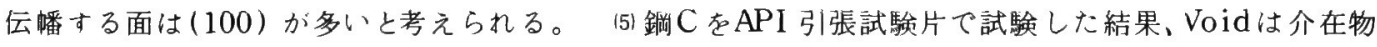

(A.B.C系)在核として発生し、伸びの增加と共に大きさ及び数圭增し A 系B系介在物に沿。て連結が認 められセパレーションに至った。(Iv)引用交献 (1) 式 P.W. Bridgiman T.A.S M vo $\ell 32$ P. 553 574

表 1 供試鋼の化学成分

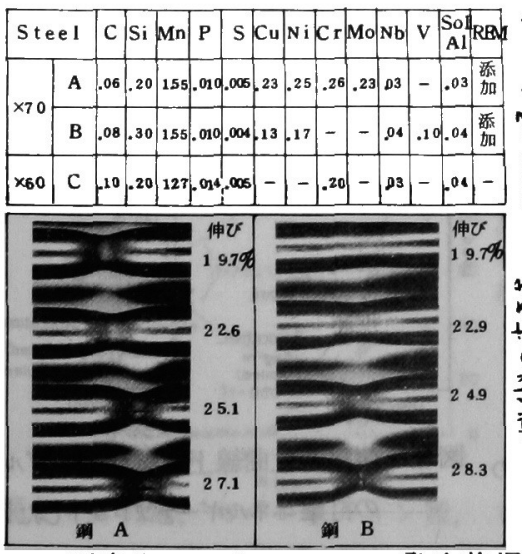

写真 1 セパレーション発生状況

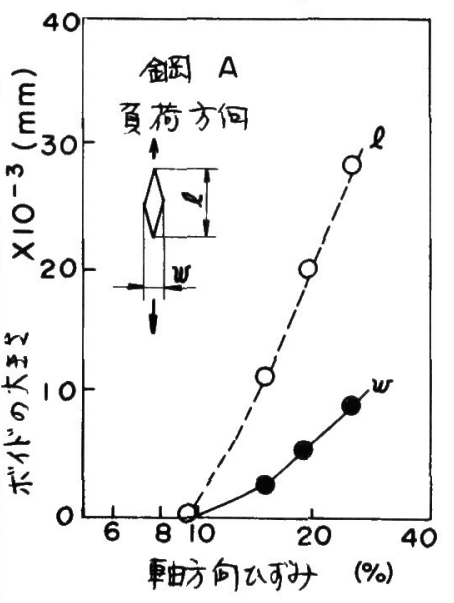

図 1 軸方向昰とVoidの大きさの関係

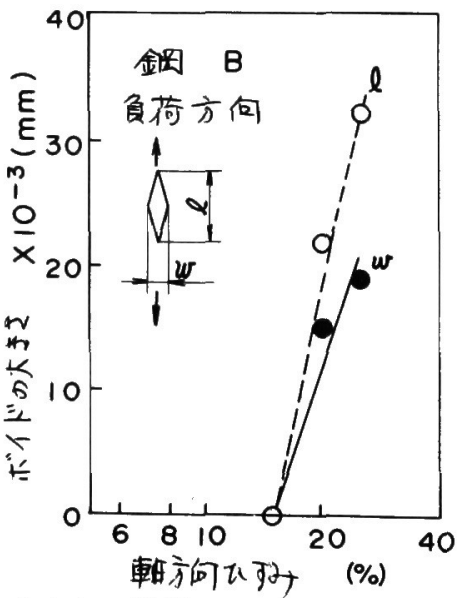

$-213-$ 
（216）衝撃荷重によって生じるセパレーションの発生について

(ラインパイプ材に扑けセパレーショ発生過程の考察その 2 )

日本鋼管技研福山哲夫平忠明

平林清照

福山製鉄所 松本重康

1)緒言： 高級ラインパイプ材のセパレーションは引張で発生し難くても、衝撃荷重の場合著しく発生す る。この種の清浄鋼を中心に市販用軟鋼と比較してセパレーションの発生過程を調べた。更にD WT Tに ついても打撃エネルギーを変えて実験し、セパレーションの発生過程を調べた。

П) 実験方法：計装シャルピー試験機を用いて荷重一変位曲線を求めだ(㘠 1 )。次にハンマーの持上角度 を変える事により破断に至る迄の変形量在段階的に変化させ割れの状況を観察し、荷重一変位曲線と 中止め試験片を比較して、七パレーション発生過程を調べた。DWTTについても打撃エネルギーを变え て実験した。本実験に供試されたラインパイプ材の化学成分と清净度を表 1 に示す。

m) 結果：(1) 清浄鐝てある鋼A.Bのセパレーションは顕著であるが非清浄鋼の鋼 D は 発生しなかった。(写真

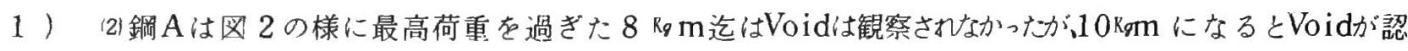
められた。12 kgm，14 kgmになるに従い割れは成長し10倍の拡大でも観察されるようになり、14 kg mて セパレーションが形成した。この場合いずれの割れの先端にも介在物は観察されなかった。鋼Bに関して も同様の発生過程であった。セパレーションの顕著に出る遷栘領域では粒界及び $(100)$ 面で割れが発生い 圧延面に平行に $(100)$ が多くある場合にはセパレーションに発展すると考えられる。 (3)鋼Dに関しては 最高荷重を過ぎた $2 \mathrm{~kg} \mathrm{~m}$ でSulfideに沿った割机が観察さ㧈小さなVoidが出て来る。破断した $3 \mathrm{kgm}$, $4 \mathrm{~kg} \mathrm{~m}$ では、セパレーションが発生しないが、Sulfide 右う割机が数多く観察された。D俳清浄鋼で ありしかもラテラルコントラクションも少い事とかなり広範囲に割れが形成される為 3 軸応力度が緩和さ れて、セパレーションに至らないものと考えられる。

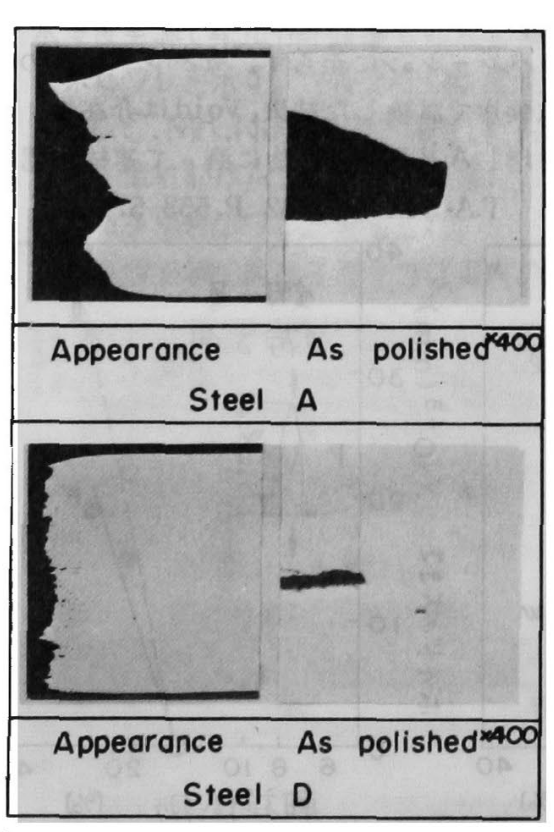

写真 1 セパレーションの登生状況

表 1 供試鋼の化学成分と清浄度

\begin{tabular}{|c|c|c|c|c|c|c|c|c|c|c|c|c|c|c|c|}
\hline \multicolumn{2}{|c|}{ Ste e I } & C & $\mathrm{Si}$ & & $\mathbf{P}$ & $\mathrm{s}$ & & $\mathrm{Ni}$ & & $\mathrm{Mo}$ & $\mathrm{Nb}$ & $\mathrm{v}$ & Sol & REM & 清桻度 \% \\
\hline \multirow{2}{*}{$\times 70$} & A & .06 & .20 & 155. & 010 & 008 & 23. & .25 & & .23 & .03 & -1 & .03 & 添加 & .042 \\
\hline & B & .08 & .30 & 155 & 010 & 004 . & 13 . & 17 & - & - & .04 & 10 & .04 & 添加 & .040 \\
\hline $\mathrm{SS}_{41}$ & 2 & & & & & 22 & - & - & - & - & - & - & - & - & .128 \\
\hline
\end{tabular}

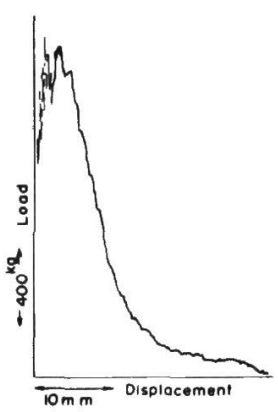

図 1 .

\section{荷重変位曲線}

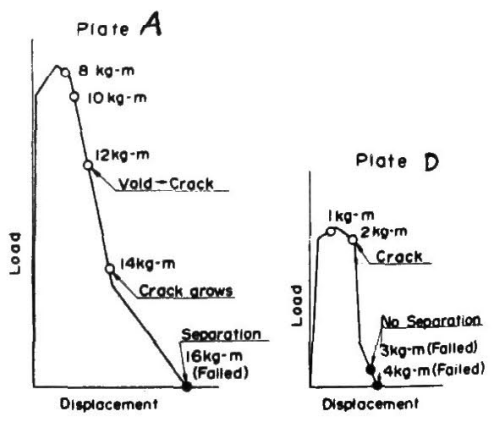

図2. 荷重変位曲線上に試験サンプル の打撃エネルギーをプロットした図 (図の数字は打幋エネルギー) 


\title{
(217) コントロールド・ロールド材のセパレイションに及ぼすNの影響
}

\author{
川崎製鉄(株)技術研究所波戸村太根生工博○田中智夫 \\ 田畑綽久
}

1. 緒言 コントロールド・ロールド材のシャルピー衝撃試験片破断面に現われるセパレイションに ついては，その発生原因を（100）集合組織や非金属介在物に求める考之が強い。しかしながら，板厚方 向（Z方向）の脆性破壊強度の低下がセパレイションを誘発するのであるとすれば， Z 方向の破壊強度 を低下させる因子はいずれもセパレイションを誘発すると考えてよい。（100）集合組織はセパレイショ ンを誘発する有力な原因ではあるが，すへててではなくその一因ということになる。集合組織や非金属介 在物以外にもセパレイションを引き起こす一例として，本報告ではNの影響を述べる。

2. 実験方法 供試材は0.1 C-0.3Si-1.3Mn-0.06 Nbをべースとして，これに た鋼である。压延方法として三条件を選んだ。すなわち（i ） $1200^{\circ} \mathrm{C}$ 加熱 $-900^{\circ} \mathrm{C}$ 仕上, (ii) $1150^{\circ} \mathrm{C}$ 加 熱- $860^{\circ} \mathrm{C}$ 仕上，（iii） $1150^{\circ} \mathrm{C}$ 加熱- $730^{\circ} \mathrm{C}$ 仕上である。セパレイションの定量法としては板面に平行 に0.5mm間隔の平行線を引きこれらとセパレイションとの交点の総数を以てセパレイション数とした。 またセパレイションの測定は延性破面率100\%の試片について行った。

3 . 試験結果図1にN量と $\mathrm{E}_{\mathrm{SA} 100}$ （延性破面率 $100 \%$ になるときの吸収エネルギー），七パレイシ ヨン数, (200) 集積度との関係を示す。 $730^{\circ} \mathrm{C}$ 仕上材では（100）集合組織が若干発達している。し かしその集積度は $\mathrm{N}$ 量によって変化しない。E sA100 は全体的に低い水準にあるが， N量の增加とともに 更に低下する。セパレイション数は $\mathrm{N}$ 量の増加につれて急激に増加する。 $860^{\circ} \mathrm{C}$ 仕上材, $900^{\circ} \mathrm{C}$ 仕上材

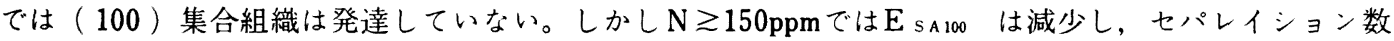
が増加する。以上の結果によれば（100）集合組織の発達している材料により多くのセパレイションが 発生するが，集合組織と無関係に $\mathrm{N}$ 量の増加とともにセパレイション数が増加することも確かである。 図 2 は内部摩擦法で測定した固溶 $\mathrm{N}$ 量と $\mathrm{E}_{\mathrm{SA} 1100}$ との関係を示す。固溶 $\mathrm{N} の$ 増加につれて $\mathrm{E}_{\mathrm{SA} 100}$ は減少す る。しかし（100）集合組織をもつ $730^{\circ} \mathrm{C}$ 仕上材と集合組織をもたない $860^{\circ} \mathrm{C}$ 仕上材の間には $\mathrm{E}$ sA100に 大きな相違があり，固溶 $\mathrm{N}$ 量のみにて $\mathrm{sA100}_{\mathrm{A} 100}$ あるいはセパレイション数を説明することはできない。

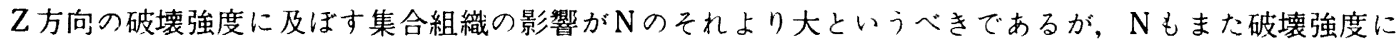

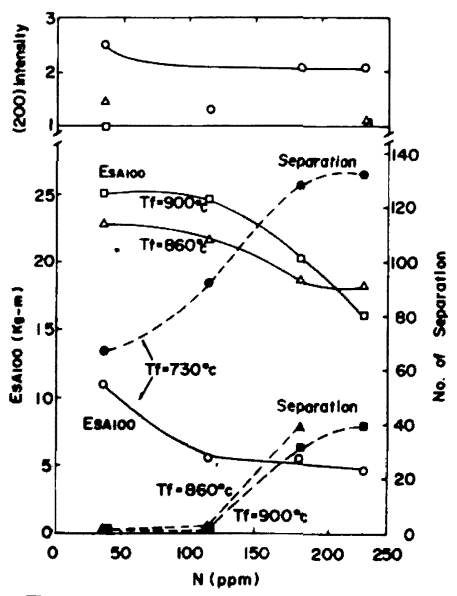

図 1 E sA100, セパレイション数, (100) 強度に及ほす加工温度の影響
影響を与えていることも確かである。

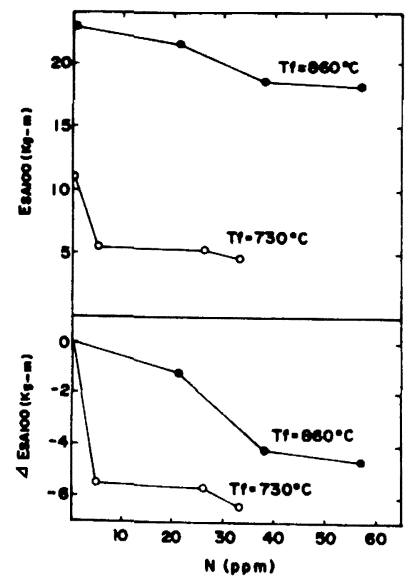

困2 固溶 $\mathrm{N}$ 量とEsA100 との関係 
川崎製鉄技術研究所。志賀千晃，工博田中智夫 工博 藤元克己，工博 舩越督己 1. 緒言 ラインパイプ用鋼林の行揧試験で破面以観察されるセパレーションの成因としては、板 面以平行な\{100\}集合組織，伸延状介在物，旧オーステナイト粒果の焼もどし脆性，艺の他いろいろ

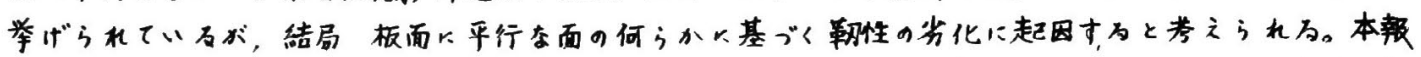

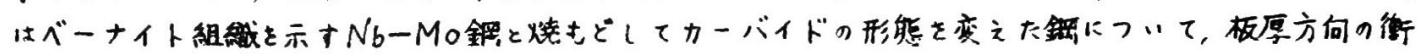

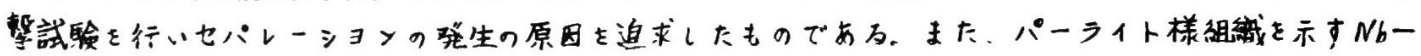
V的ついても同時に調べ比較した。

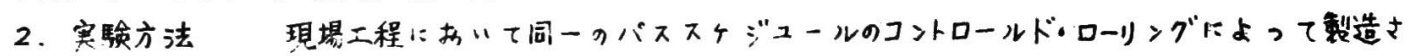

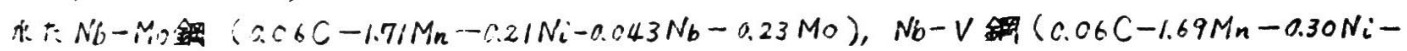

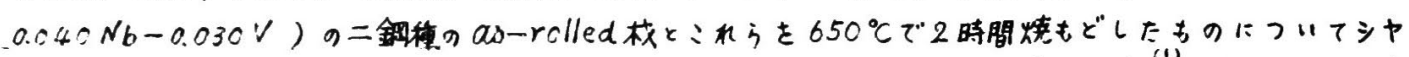

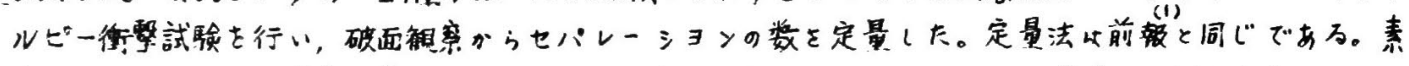

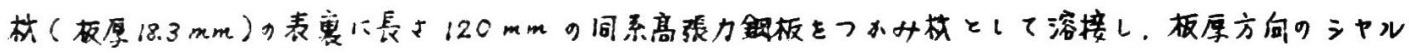
ピー坛稌片とした。

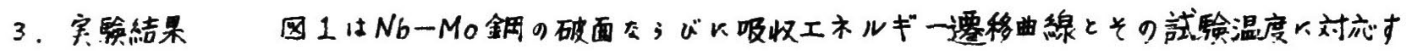
るセパレーション数を示したもので，点線はas-rolled

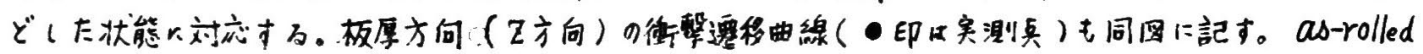

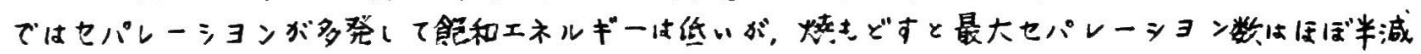

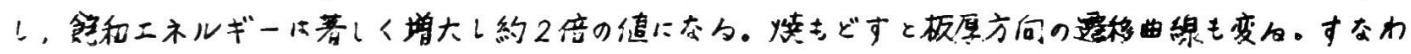

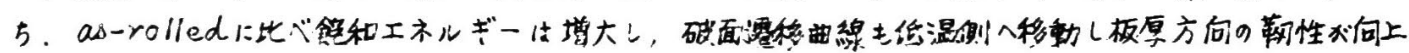

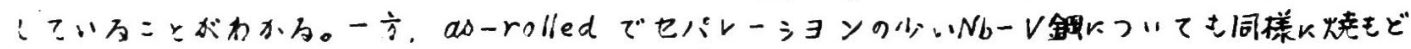

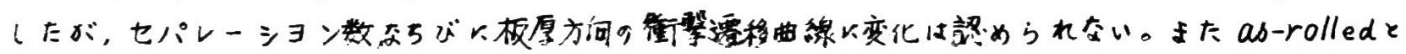

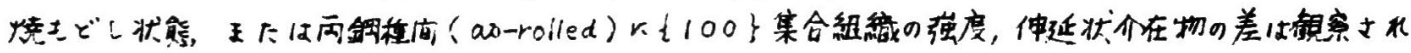

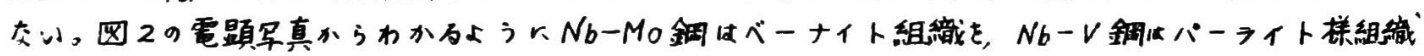

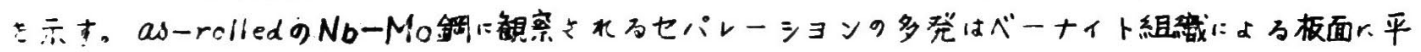

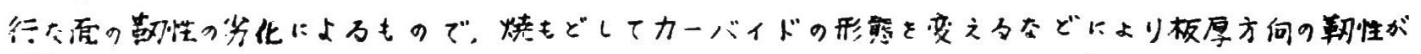

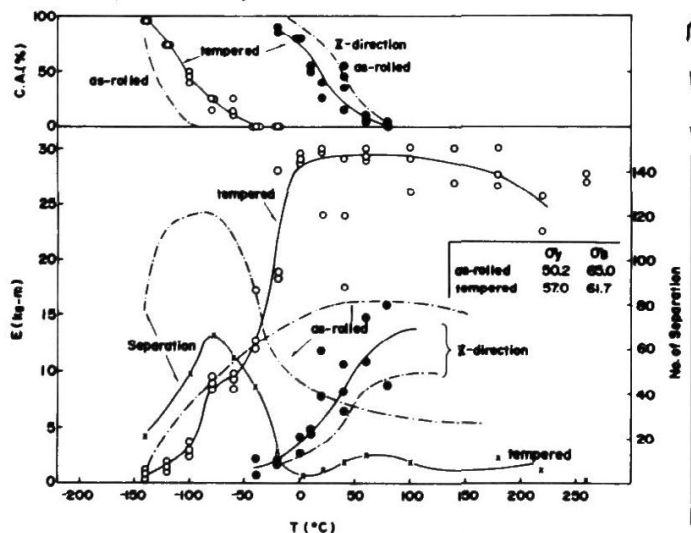

因1衡慗悉移曲線とセパレーション数の周䋆 向上寸るとセパーシヨン数減少する。しかしNb-

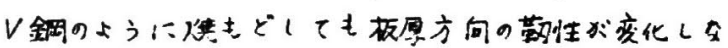
いまのはセパレーシヨン数さ変う公いと结㻅されか。

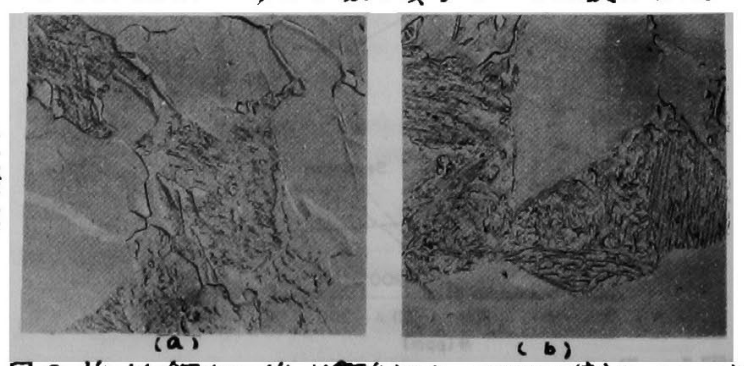

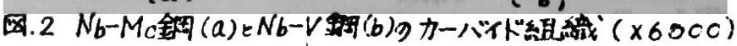

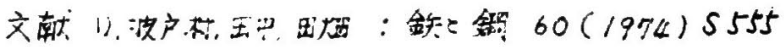




\section{（219） Nb添加鋼の低温圧延における変形帯の形成}

新日本製鉄基磷研究所関根宽, ○丸山忠克 川島善樹果

\section{1. 緒言}

前報では， $\mathrm{N} b$ 添加銅においてオーステナイト $(r)$ の未再結晶域での王延を行ならと, (1)板厚方向の

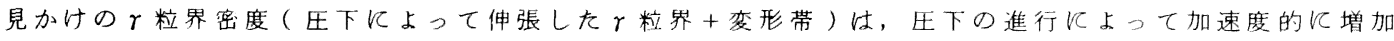

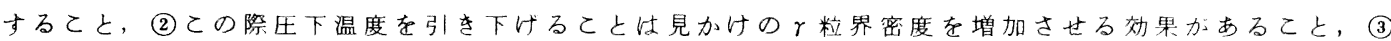

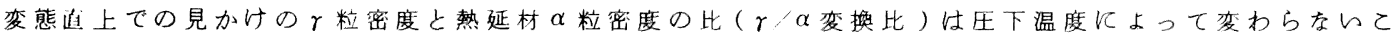
とを明らかにした。今回はN b 添加鋼についてrの未再結晶域区延で形成される変形带の密度和上びそ の均一度に対する压下率および連続压下の効果につんて調べた。

\section{2 実験方法}

供試銅伎表 1 亿成分を示す真空溶解銅で，予備熱延後所定の小スラブを切り出し実験に供した。熱延

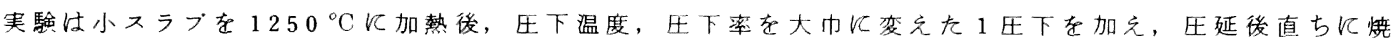
入れた試片のL断面につんて板厚方向の見かけの＼cjkstart粒界密度，均一度の測定在行李った。ついで同しく

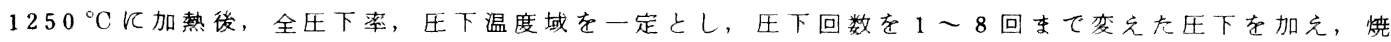
入れ後同様な測定を行なった。尚本夷験では压下前の $r$ 粒度 $(\mathrm{N} r \mathrm{i})($ 表 1) および区下時の口一ル回転 速度は一定とした。

\section{3. 実験結果}

（１）１压下で形成される变形带を含む見かけのと粒界密度お 上び均一度は，压下率加高く压下温度が低い洼ど增加する。 a)压下温度が一定の条件では、压下率を增すにつれて見か

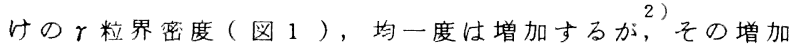
の度合々注压下率 30 \% で飽和する傾向を有する。

b)殴下率一定の条件では，压下温度の低ら方が見かけのr 粒界密度は高くなるが, その均一度恃夷験した温度範用で は在とんと変化しない。

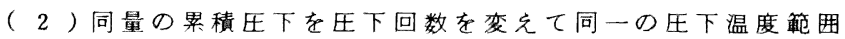
で与えると，殴下回数が少なく1圧下当りの王下率か高いも のの方が見かけの $r$ 粒界密度および均一度は增加する。乙の 場合にも1压下当りの压下率が 30 \%以上では, これらの压 下回数依存性は認められなくなる。（眓2）

以上のととから, $\mathrm{Nb}$ 添加鋼のコントロールドローリンクにお いてNriが一定の場合（すくなくとも $\mathrm{Nr}$ i が粗粒のとを）飞は, ケの未再結晶域での压下温度を低くすることのほかに，末再結 晶域の各パス压下率を30\%に近つけるよ5にできるだけ大 をくとる必要のあるととかわかる。

文献 (1) 丸山, 影山, 関根 : 鉄之鎆, 57( 1971$)$ S 282

(2)梶，勝亦，町田，木下：鉄と鍼，60(1974)S295

(3)松原，大須賀，小指，束田：鉄と鋼，58(1972)P1848 表 1 供試鋼の化学成分と $\mathrm{N} r \mathrm{i}$

\begin{tabular}{|c|c|c|c|c|c|c|}
\hline 種 & $\mathrm{N} \gamma \mathrm{i}$ & $\mathrm{C}$ & $\mathrm{S} \mathrm{i}$ & $\mathrm{Mn}$ & $\mathrm{Nb}$ & $\mathrm{N}$ \\
\hline $\mathrm{A}$ & -0.1 & 0.095 & 0.22 & 1.38 & 0.044 & 0.0025 \\
\hline $\mathrm{B}$ & -2.5 & 0.096 & 0.28 & 1.47 & 0.056 & 0.0055 \\
\hline
\end{tabular}

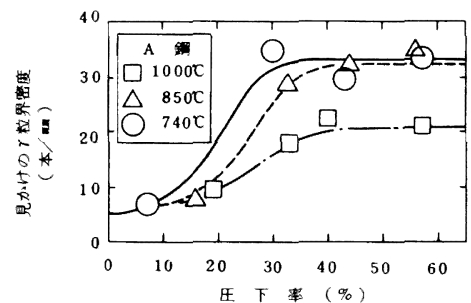

圆 1. 見かけのr粒界密度に与充る圧下率の影響

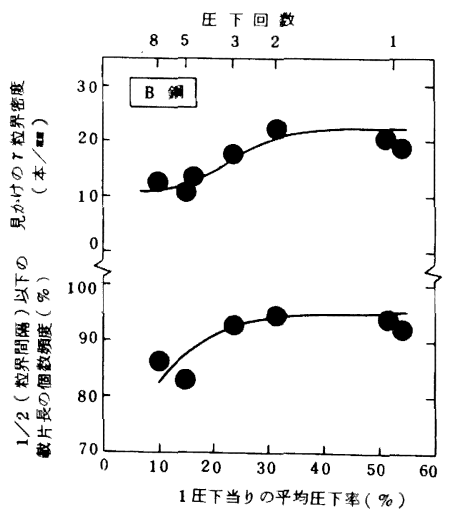

図 2. 見かけの に与える累積压下率の影壁 


\title{
$74-\mathrm{S} 558(220) \quad 669.15 ' 293-194: 669.112 .227 .1: 548.53$ \\ $\mathrm{Nb}$ 添加鋼の熱間圧延における再結晶オーステナイト微細化の効果
}

\author{
新日本製鉄基礎研究所関根寞, ○丸山忠克
}

\section{1. 緒 言}

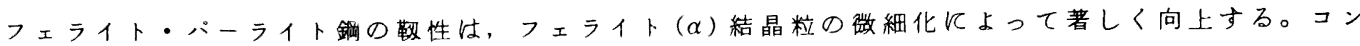
トロールト゚・ローリンク（CR）は，熱間王延工程の制衔を通してての 発展してをた。すなわち $\alpha$ 粒微細化には，変態前のオーステナイト（r）状態での加工によって変態時の $\alpha$ 核発生サイトを富化しておくことが有効であり, $\mathrm{Nb}$ 添加鋼の C R 手段として広く実施されている低温 域（rの未再結晶域）王延の強化も，てのような内容をもっている。しかし変態時の $\alpha$ 核発生サイトを 增やすためには低温压延以外飞る，rの再結晶の進行する高温度域ての开下によって再結晶 $r$ 粒を微細 化する方法も考えら机る。本報では, とくにこの して, 広範字験室王延材につんてその特性を比較した。表 1 . 供試鋼の成分（wt\%）

\section{2 実験方法}

供試鋼は表 1 亿成分を示す転炉溶製鋼で，分塊王延

\begin{tabular}{|cccccccc|}
\hline $\mathrm{C}$ & $\mathrm{Si}$ & $\mathrm{Mn}$ & $\mathrm{Nb}$ & $\mathrm{V}$ & $\mathrm{A} \boldsymbol{\ell}$ & $\mathrm{S}$ & $\mathrm{N}$ \\
\hline 0.11 & 0.26 & 1.36 & 0.048 & 0.043 & 0.037 & 0.007 & 0.0037 \\
\hline
\end{tabular}

により150mm厚としたすのを素材として用いた。この素材鋼片から子備正延によって種々の厚みを有す る熱延実験用スラブを作製した。熱延実験の概要は図 1 に示すよ 5 ス，スラブ加熱 $1250^{\circ} \mathrm{C} \times 1 \mathrm{hr}$, 高温域

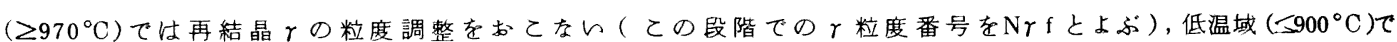
は未再結晶域の累積压下率 $\left(\sum \mathrm{r}\right.$ の記号で示す) を大巾に変え, 一方向迁延によっていすれれ $800^{\circ} \mathrm{C} て 13 \mathrm{~mm}$ 厚に仕上げた。 Nrfはー3から7番まで， $\mathrm{r}$ は 0 から90\%李で変化させて，熱延材の組織と材質を調べた。

\section{3. 実験結果}

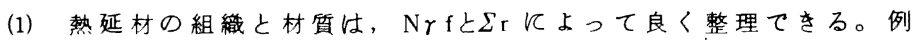
えば， $\alpha$ 結晶粒度については図2亿示す通りである。

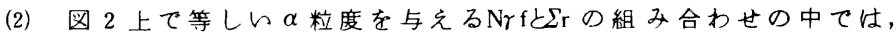

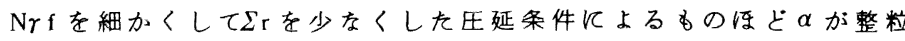
で上部へイナイトの混入す少去ん。

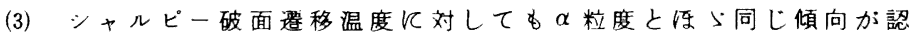
められ、 $\mathrm{Nrf}$ での1番の細粒化は， $\sum \mathrm{r}$ t 60 加 70 \%に 10 \% 程 度增加させるのと同等の効果をるたらす。

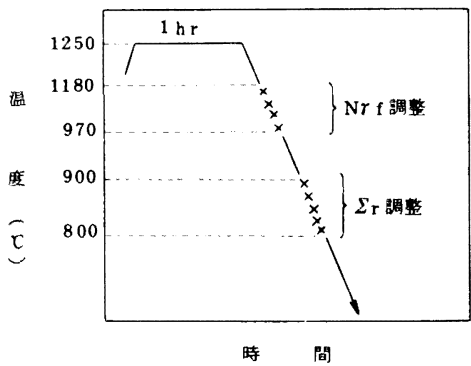

図 1. 熱延奏験の概 要

(4) 王延直角方向のシャルピー試験てのシェルフ エネルギー值は， $\sum \mathrm{r}$ が約 $70 \%$ 越えると急激に低 下する。したがって一定の破面要移温度を与える $\mathrm{N} \gamma \mathrm{f}$ と $\mathrm{r}$ の組み合わせの中で， N r f が細粒のも のほどシェルフェネルギ一値は高くなる。

以上のよ $5 飞, \mathrm{~N} r \mathrm{f}$ の積極的細粒化をとり入れ た C R Kは，低温王延を主体とした方法にくらへ ていくつかの長所があ。また C R 亿伴なら生産 能率の低下をさける点からる，rの再結晶の起り 得る高温域ての王下に重点を固いて低温压延への 依存度を弱めるととが有効であると考えられる。

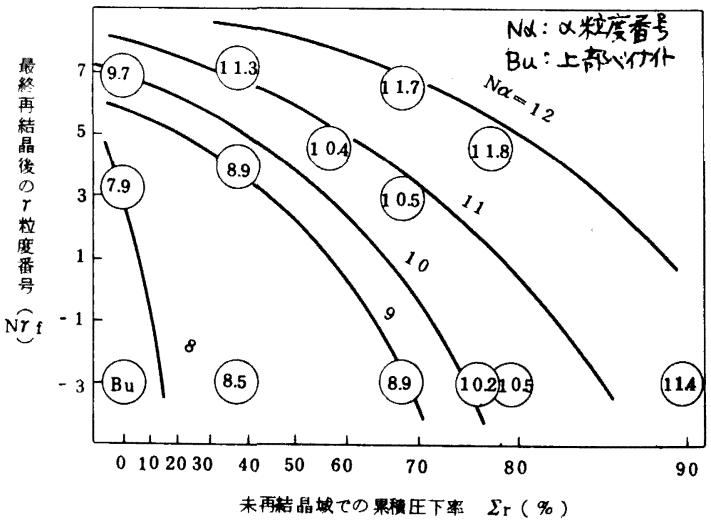

図 2. $\alpha$ 粒度に対する王延条件の影 


\section{（221） Nb添加鋼の熱間圧延条件と集合組織}

新日本製鉄基礎研究所 $\bigcirc$ 松尾宗次, 丸山忠克

関根 寞

1. 緒言

熱延材の組織, 材質はフェライト $(\alpha)$ への変態前のオーステナイト $(r)$ 状態, とくに再結晶してい

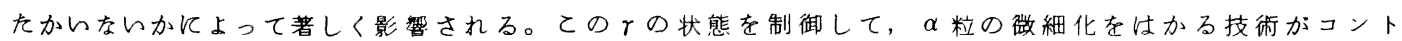

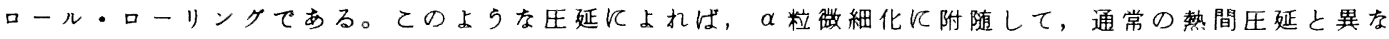
り熱延板 $\alpha$ 相にかなり顕著な集合組織の形成加認められる。集合組織の発達はrの压延集合組織の発達 と $r \rightarrow \alpha$ 変態時の方位選択性飞与とうくものと考えられている。

面心立方金属の压延集合組織は交叉すべり頻度により著しく影䇾されるととはよく知られている。交 叉すべりの頻度は積層欠陥エネルギー, 加工温度によって変化し, それ以外飞結晶粒度, 歪細析出物に よっても影響を受けるととが期待される。とのよらな観点にもとうう，て粒度およびての未再結晶域珅 下率を大巾凡変化させて，熱延材の $\alpha$ 粒度，材質に明確な差異を示した別報（関根，丸山：本誌，前ぺ 一 シ)の試料を用いて，熱延板 $\alpha$ 相集合組織を調査した。

\section{2 実験方法}

供試料：上掲別報に用いた試料，すなわち高温域熱延て $r$ 粒度を調整し，次いで 延の累積压下率を変化させたものである。

集合組織測定：上記試料の板厚中心層，表面層の集合組織正極点図により観測，必要に応して三次 元表示結晶方位解析法飞より方位成分解析を行なった。

\section{3. 実験結果}

(1) $\alpha$ 集合組織は $\gamma$ 粒度および

(2) $\quad r$ 粒径が小さい場合， $\alpha$ 集合組織㤌王延方向に<110>方向が平行なせんい組織である。

(3) $\quad r$ 粒径が大さい場合，上記〈110 せ せん組織以外の方位成分が存在する。

本実験により，熱延板の集合組織形成はとが再結晶せず任延される間に形成される王延集合組織が， 高温正延時に最後に再結晶したとさのて結晶粒度にも支配されていることが示された。

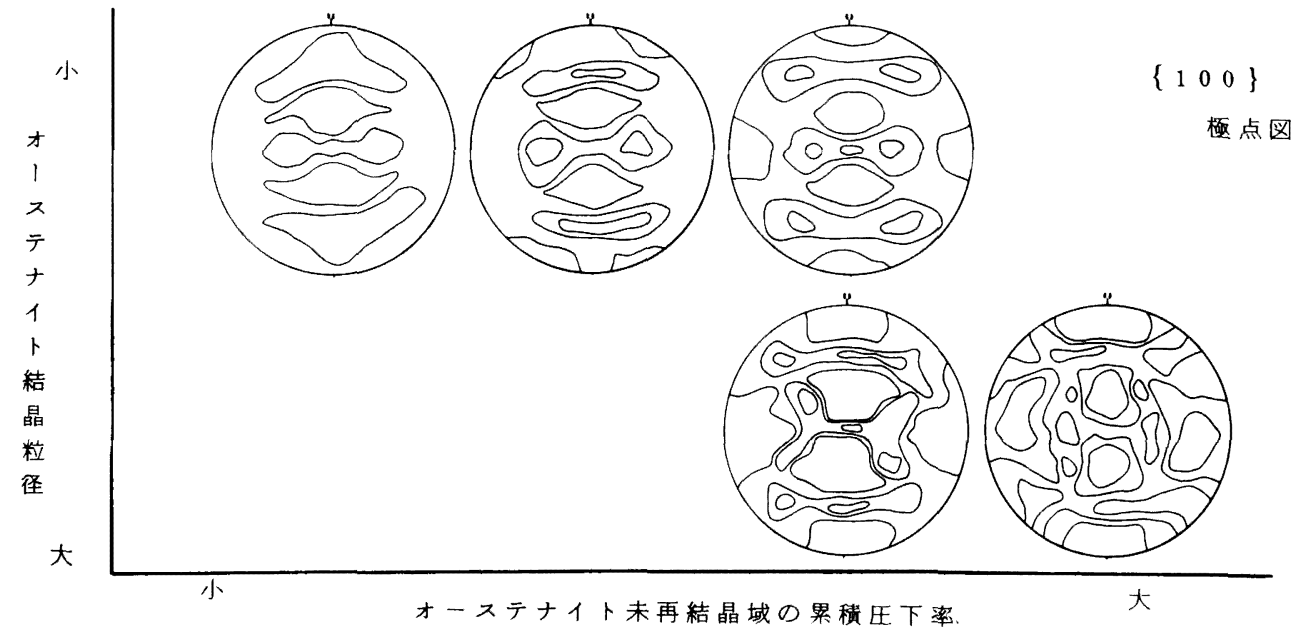

図 $1 \mathrm{~N} \mathrm{~b}$ 添加鋼の熱延条件と集合組織 
$74-\mathrm{S} 560$

669.14-157.97: 669.112.228.017.3: 539.4

（222）歪誘起による $\mathrm{Ar}_{3}$ 点の上年と機戌的性質の変化

川崎製鉄(株)技術研究所

○田畑綽久 工博 田中智夫

波戸村太根生

\section{1. 緒言}

コントロールド・ローリングに拈いては，未再結晶 $\gamma$ 域での圧下の役割は $\gamma$ 粒を伸長し粒内に変形带 を学入することにより変態後の $\alpha$ 粒を微細化することであると従来考えられてきた。しかし䒠際の压延 においては歪誘起変態により $\mathrm{Ar}_{3}$ 点が上昇するために $(\gamma+\alpha)$ 域での圧延が付加されている可能性が 多分にある。したがってコントロールド・ローリングの意味を正確に把握するためには，歪誘起 $\mathrm{Ar}_{3}$ 点 を測定し、 $\gamma,(\gamma+\alpha)$ 域での圧下による機械的性質等への影響を区別して考えることが必要である。 本報では以上のことを念頭において実験を行ったものである。

2. 実験方法

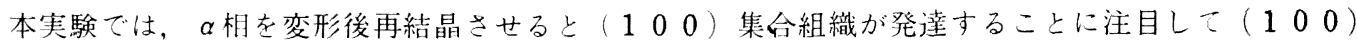
強度の変化から間接的に $\mathrm{Ar}_{3}$ 点を求める方法をった。

供試鋼は Nb材 $\left(0.11 \% \mathrm{C}-0.24 \% \mathrm{Si}-1.35 \% \mathrm{Mn}-0.035 \% \mathrm{Nb}-0.038 \% \mathrm{~V}-0.034{ }^{\circ} \circ \mathrm{A} \ell\right)$ である。こ れを1 $1500^{\circ} \mathrm{C} \times 60 \mathrm{~min}$. 加熱後，コントロールト・ローリングに供した。コントロールド・ローリン グ条件は $1150{ }^{\circ} \mathrm{C}-950^{\circ} \mathrm{C} 5$ パスで $50 \%$ 压下与之た後, $900^{\circ} \mathrm{C}, 850^{\circ} \mathrm{C}, 800^{\circ} \mathrm{C}, 750^{\circ} \mathrm{C}$, $700^{\circ} \mathrm{C} ， 650^{\circ} \mathrm{C}$ 各温度で( i ) 1 パス，30\%の圧下を与えた。(この方法により歪のない $\gamma$ 粒の $\mathrm{Ar}_{3}$ 点を測定できる。)，(ii） 2 パス， $50 \%$ の圧下を与えた。（この方法により歪誘起 $\mathrm{Ar}_{3}$ 点を測定でき る。）以上の 2 方法により通常の $\mathrm{Ar}_{3}$ 点, 歪誘起 $\mathrm{Ar}_{3}$ 点を求めた。

3 . 実験結果

図 1 は 1 パス，30\%又は 2 パス，50\%の圧下を与えた温度上圧延面に平行に発達した（200）強 度との関係をプロットしたものである。

1 パス，30\%压下の場合， $750^{\circ} \mathrm{C}$ 以上では集合組織の発達 は起こっていない。700 $0{ }^{\circ} \mathrm{C}$ 以下では低温になるにしたがい $(2$ $\left.\begin{array}{ll}0 & 0\end{array}\right)$ の集積度は增加する。すなわち歪のない $\gamma$ 粒の $\mathrm{Ar}_{3}$ 点は約 $725{ }^{\circ} \mathrm{C}$ となり, これは変態点测定装置による測定值とよく一致 する。

2 パス，50\%压下の場合， 1 パス，30\%の時と同様の傾向 を示すが，全体的に $50{ }^{\circ} \mathrm{C}$ 程度高温側にシフトしている。すなわ ちこの場合, 歪誘起 $\mathrm{Ar}_{3}$ 点は $775^{\circ} \mathrm{C}$ 近傍にあることになる。2 パス, $50 \%$ 圧下の場合, $750^{\circ} \mathrm{C}$ 以下の压延は $(\gamma+\alpha)$ 域で 行われたことを意味する。 $\gamma$ 域の圧延と $(\gamma+\alpha)$ 域の圧延とでは 機械的性質に大きな相違を生じる。 降伏応力, $\mathrm{Nb}, \mathrm{V}$ 析出量, セパレイション数はほぼ一定レベルで あるが $750{ }^{\circ} \mathrm{C}$ 以下では温度の低下に伴い急激に增加する。した

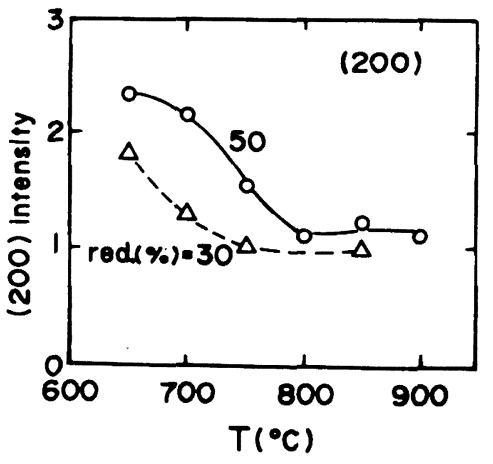

図 1 圧下温度と（200）集合組織 との関係 がって逆にこれらの諸性質の不連続性を利用することにより歪誘 起 $\mathrm{Ar}_{3}$ 点の推定が可能となる。しかし本実験で用いた集合組織の集積度の変化によるものが特に有効で ある。

1）田中, 波戸村, 田畑： 鉄鋼協会 昭和 49 年.度秋期講演大会 


\subsection{4-157.97: 669.112.228.017.3 \\ $744-\mathrm{S} 561$ \\ （223）コントロールド・ロールド材に及ぼす $\gamma,(\gamma+\alpha)$ 域での圧下の影響}

川崎製鉄(株)技術研究所 ○工博 田中智夫 波戸村太根生 田畑綽久

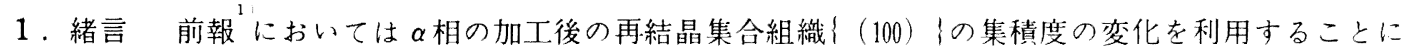
よって歪誘起による $\gamma \rightarrow \alpha$ 変態温度の測定を行った。本報はこの方法を用いて $\gamma$ 域と $(\gamma+\alpha)$ 域とを 区別し、各領域における圧下の役割を明らかにしょうとするものである。

2 . 実験方法 供試鋼は現場工程を経て得られた $\mathrm{Nb}-\mathrm{V}$ 材 $(0.11 \% \mathrm{C}-0.24 \% \mathrm{Si}-1.35 \% \mathrm{Mn}-0.035$ $\% \mathrm{Nb}-0.038 \% \mathrm{~V}-0.034 \% \mathrm{~A} \ell)$ 加実験圧延用スラブを作成し， $1150{ }^{\circ} \mathrm{C} \times 60 \mathrm{~min}$.の加熱後，コン トロールド・ローリングを行った。コントロールド・ローリングの低温側については $\gamma$ 域, $\quad(\gamma+\alpha)$ 域での圧延の影響が顕著に現われる様な条件を選定した。

3 . 実験結果図1は1150９50 ㄷ゙ $50 \%$ の圧下を与 えた後, 横軸の各温度で $50 \%$ の圧延を行った場合の降伏応力, セパレイション数, Nb、Vの析出量, 延性破面が $100 \%$ になる 時の吸収エネルギー（E SA100），（200）強度の変化を示す。 ( 200$)$ 強度の変化から $800^{\circ} \mathrm{C}$ 以上は $\gamma$ 域, $750^{\circ} \mathrm{C}$ 以下では（ $\gamma+\alpha)$ 域の圧延であることが分かる。 $8000^{\circ} \mathrm{C}$ 以上の $\gamma$ 域で圧 延した場合, 降伏応力のレベルは低い。また圧下温度による影響 は小さい。この傾向はセパレイション数, $\mathrm{E}_{\mathrm{SA100}}, \mathrm{Nb}, \mathrm{V}$ 析出量 についても同様である。他方 $750{ }^{\circ} \mathrm{C}$ 以下の $(\gamma+\alpha)$ 域で圧延 した場合, 圧下温度の低下に伴い降伏応力, 七パレイション数,

$\mathrm{Nb}, \mathrm{V}$ の析出量の急激な增加がある。またセパレイション数の增 加に起因してE sA100の減少が起こク, 図に示していないが, 破面 遷移温度の著しい低下が見られる。

この様に $\gamma$ 域, $(\gamma+\alpha)$ 域における圧延の効果は著しく異な る。奏際のコントロールド・ローリングでは強度, 靸性の最適バ ランスを $\gamma$ 域と $(\gamma+\alpha)$ 域の圧延の比率で達成している。表 1 はコントロールド・ローリングを構成する 3 段階と各段階での諸 性質の変化を概念的に示したものである。

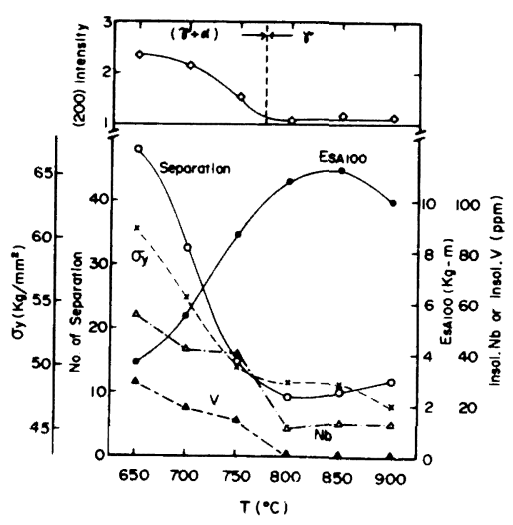

困 1 圧下温度と降伏応力 $\sigma_{y}, \mathrm{E}_{\mathrm{SA} 100}$ , 七パレイション数, 析出量, (200) 強度との関係

表 1 コントロールド・ロ-ーリングを構成する3段階と各段階での諸性質の変化

\begin{tabular}{|c|c|c|c|c|c|c|c|c|c|}
\hline & \multirow{2}{*}{ 温 } & \multirow{2}{*}{ 組 } & \multicolumn{2}{|l|}{ 強 } & 度 & \multicolumn{2}{|l|}{ 勒 } & \multicolumn{2}{|r|}{ 性 } \\
\hline & & & 降伏応力 & 加工硬化 & 析出硬化 & 邉移温度 & E s A 100 & $\begin{array}{l}\text { セ゚゚レ1 } \\
シ ョ シ y ~\end{array}$ & $\begin{array}{c}(100) \\
\text { 重合組織 }\end{array}$ \\
\hline 第 1 段階 & $\begin{array}{c}\geq 950^{\circ} \mathrm{C} \\
\text { 再結晶 } \gamma \text { 域 }\end{array}$ & $\begin{array}{c}\text { 再結晶による } \gamma \text { 粒の微細化 } \\
\gamma \text { 粒径 }=20 \sim 40 \mu\end{array}$ & $\begin{array}{l}\text { 小 } \\
(\text { 粒度に } \\
\text { 依存) }\end{array}$ & $\sim 0$ & $\sim 0$ & 高い & 大 & なし & なし \\
\hline 第 2 段階 & $\begin{array}{r}950^{\circ} \mathrm{C} \sim \mathrm{Ar}_{3} \\
\text { 未再結晶 } \gamma \text { 域 }\end{array}$ & 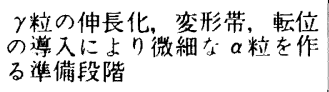 & $\begin{array}{l}\text { 小 } \\
\text { (粒度に } \\
\text { 依存) }\end{array}$ & $\sim 0$ & $\sim 0$ & \begin{tabular}{|c|} 
結晶粒度 \\
に依存
\end{tabular} & 大 & 小 & なし \\
\hline 第 3 段階 & $\begin{array}{c}<\mathrm{Ar}_{3} \\
(\gamma+\alpha) \text { 域 }\end{array}$ & 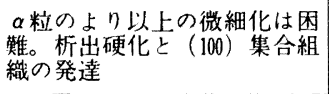 & 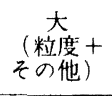 & 小 & 大 & 低い & 小 & 大 & あり \\
\hline
\end{tabular}

1）田畑, 田中，波户村：鉄鋼協会 昭和 49 年度秋期講演大会 